\title{
喉頭全摘後の音声外科的治療と発声機能
}

\author{
久留米大学医学部耳鼻咽喉科学教室 \\ 平野実, 寺沢るり子, 麻生正美,川崎洋, \\ 吉田哲二, 大久保洋
}

\section{PHONOSURGICAL TREATMENTS FOLLOWING TOTAL LARYNGECTOMY AND POST-OPERATIVE VOCAL FUNCTION}

\author{
MINORU HIRANO, M. D., RURIKO TERASAWA, M. D., MASAMI ASO, M. D., \\ HIROSHI KAWASAKI, M. D., TETSUJI YOSHIDA, M. D. \\ and HIROSHI OHKUBO, M. D.
}

Department of Otolaryngology and Head and Neck Surgery, Kurume University, Kurume

This paper describes the results of Arslan-Serafini technique in 11, Amatsu technique in 15 and Panje technique in 1 case. Post-operative vocal function was evaluated in 3 Arslan-Serafini, 5 Amatsu and 1 Panje case. Following Arslan-Serafini operation, $z$ patients became able to speak, whereas in the other 4 , the shunt was closed spontaneously or because of infection and/ or necrosis. Of the former 7,6 patients had no or only slight aspiration but the other patient suffered from severe aspiration and, therefore, we had to close the shunt surgically. Following Amatsu operation, 5 patients obtained phonatory and protective functions. In other 3 patients who became able to phonate, the shunt had to be closed because of severe aspiration. In the remaining 7 , the shunt was closed spontaneously or because of infection and/or necrosis. The patient who underwent Panje method became able to speak. There was no difference in phonatory function among the 3 phonosurgical treatment modalities. Compared to normal subjects, the fundamental frequency of voice was low, the ranges of frequency and intensity of voice were narrow and the glottal resistance and subglottal pressure were high.

Key words: 喉䫒全摘, Arslan-Serafini 法, 天津法, Panje 法, 発声機能

A87-0950-60324

\section{Iはじめに}

喉頭全摘後に食道発声を習得する率は、アメリカの様 飞言語治療士のサービスが普及している国ても約 $60 \%$ \% , 我国ては約 $40 \%$ 7である。我国では独特の笛式人工喉晊 がよく発達して乱り，食道発声と人工喉頭を合わせる と，発声機能習德率は $80 \%$ 弱になる7。.たたしこの数值 は熟達度は度外視した仵, つまり下手な人含含めた数值 である、さらに食道発声の習得には相当な努力を要する し，人工㜊頭ではロにチューブをくわえて話さなければ ならない，要するに倨頭全摘徯にスピーチ・コミュニケ
ーションの機能を習得するのは，大变なことなのであ る.

そこで訓縲による䒠のリハビリテーションの代わり に，手術によって発宛機能を再建する方法加発達してき た。 それは喉頭の全欠損儿対する音声外科的治㙩という べきものであり，その㓣始者は浅井》である。浅井の原 法は現在はほ上んど行われないが，種々の変法が世界中 で考案，実施されている。

我々む過去 10年の間飞 Arslan-Serafini 法 ${ }^{3)}$ ，天陆法

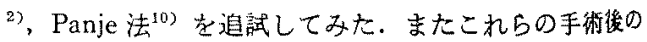


表 1 Arslan-Serafini 法施行例

\begin{tabular}{|c|c|c|c|c|c|c|c|c|c|c|c|}
\hline 症例 & 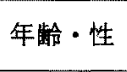 & 部位 & $\mathrm{T}$ & $\begin{array}{c}\text { 放射線 } \\
(\mathrm{rad})\end{array}$ & 発声 & 蕉下 & 呼吸 & $\begin{array}{l}\text { 伆合部閒鎖 } \\
\text { の理由 }\end{array}$ & 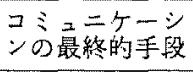 & & 備 考 \\
\hline Ar 1 & $75, \mathrm{M}$ & 声門上 & $\mathrm{T} 3$ & - & 0 & $x$ & $x$ & 商度の諰感 & 不明 & & \\
\hline Ar 2 & $73, \mathrm{M}$ & 声門 & $\mathrm{T} 3$ & - & 0 & 0 & $x$ & 再発 & 不明 & & \\
\hline At 3 & $66, \mathrm{M}$ & 声閒 & $\mathrm{T} ı \mathrm{~b}$ & $\longrightarrow$ & 0 & $\triangle$ & $x$ & & Arslan 法 & & \\
\hline Ar 4 & $66, \mathrm{M}$ & 声門 & $\mathrm{T} 3$ & $\longrightarrow$ & $x$ & $x$ & $x$ & 感染・填死 & 筆談 & & \\
\hline Ar 5 & $62, \mathrm{M}$ & 声門 & $\mathrm{T} 2$ & 3000 & 0 & $\triangle$ & $x$ & & Arslan 法 & & \\
\hline Ar 6 & 6?, M & 声門上 & $\mathrm{T} 2$ & - & $x$ & $x$ & $x$ & 感染・壊死 & 食道発声 & & \\
\hline Ar 7 & $71, M$ & 声門 & $\mathrm{T} 2$ & - & $\bigcirc$ & 0 & $x$ & & Arslan 法 & & \\
\hline Ar 8 & $53, \mathrm{M}$ & 声閒 & $\mathrm{T} 2$ & 7000 & $x$ & $x$ & $x$ & 婜染・褧死 & 食道発声 & & \\
\hline $\operatorname{Ar} 9$ & $55, \mathrm{M}$ & 声門 & T1a & 6000 & 0 & 0 & $x$ & & Arslan 法 & & \\
\hline Arlo & $55, \mathrm{M}$ & 声門 & $\mathrm{T} 2$ & 6000 & 0 & $\triangle$ & $x$ & 自然閉鎖 & 筆談 & 一是䛭 & $\begin{array}{l}\text { Arslan 法て } \\
\text { 胃癌の手術 }\end{array}$ \\
\hline Arl1 & $71, \mathrm{M}$ & 声閒 & Tra & 6000 & 0 & $\triangle$ & $x$ & 気管孔開大手 & 街 Panje 法 & 一暲 & Arslan 法て \\
\hline
\end{tabular}

発声; $\bigcirc$ 会話可能, $\times$ 発声不能

呼吸: $\times$ 経鼻呼吸不可能

発声機能を検討した，本論文ては各手衔法の成績上術後 の発声機能について報告する。

\section{II手術の成樍}

1. Arslan-Serafini 法

11例化本法を施行した（表 I），全例男性で，年秢は 53〜75歳である．9例は声門癌，2例洁声閒上缥の症例 である，放射線を煦射されていた例が5例ある。6,000 $\operatorname{rad}$ 以上の 4 例（症例 Ar 8，9，10，11）性放楾治療 後の再発例である。3,000 rad 照射の例（症咧 Ar 5)は， 放射線が効かないので，手術化切り替克た例である，

11 例中 8 例（症例 Ar 1, 2, 3, 5, 7, 9, 10, 11）は術 後発声ができるようになった。そのうち 3 例（症例 Ar 2,7，9）で蛅照はなく，4例（症例 AI 3，5，10，11） では術後しばらくの間，軽度の鿁曣があったが，経過と ともににんと消失した，残りの1例（症例 Ar 1) は， 譟祭が高度で，気管咽再吻合部を閉銷せさるを得なくな った，呼吸に関しては全例気管孔を必要しした。たた し，大きな気管孔でなく，裂搼状の気管孔で十分な例も ありそれらの例では発声に際して指で気管孔をふさぐ 必要はない。

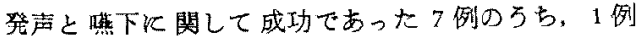
(症例 Ar 2) では，I年 4 力月後化瘦加再発し，Zれに 対する手術の折に，気管亡咽頭の吻合部を除去したた
め，吻合枯なくなってしまった．別の1例（症例 Ar 11) では，気管孔が狭くなり，これを開大するときに吻合部 加閉鎖されてしまった，651例（症例 Ar 10）では吻 合部㘦，いつの間にか自然閉鎖しその俊は筆談をしてい る.

11 例中の残り 3 例（症例 Ar 4，6，8）て证感染中㙥死 のため気第咽頭吻合部加閣鎖してしまった。しかしこれ 5のうち2例（症例 Ar 6，8）で虫食道発で日常会話 ができる. 残り1例（症例 ArA）は筆談をしている.

以上を要約するとArslan-Serafini 法を行ったい例中， 発声機能に関しては 7 例, 㔈下時の気道保護に関しては これらのうち6例で成功し，呼吸道に関しては全峢気管 孔を必要しした。

2. 天津法

15例に本法を試行した（表2）．14例は瘦の症例であ るが，1例（表 2 の症例 Am 15）は乳頭腫の症例であ る.

男性12例，女性 3 例で，年龄は48〜25歳てある.天津 法ては図1左のよ5に気管と食道の側々昒合するのであ るが，この方法では吻合部が自然閉銷する例があったの で，図1古のように端側伆合を行ってみた例むある（表 2 中* 印).

15例中10例（症例 Am 2 4, 8 13, 15）が一虑発声 可能となった、そのうち会話がで恶るようになったのは 
表 2 天津 法施 行 例

\begin{tabular}{|c|c|c|c|c|c|c|c|c|}
\hline 症例 & 年齢・性 & 部位 & $\mathrm{T}$ & 発声 & 䓵下 & $\begin{array}{l}\text { 吻合部閉銷 } \\
\text { の理由 }\end{array}$ & 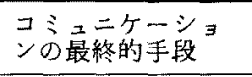 & 備 \\
\hline Am 1 & $69, \mathrm{~F}$ & 声門 & $\mathrm{T} 3$ & $x$ & 0 & 自然閉鎖 & 筆談 & \\
\hline Am 2 & $52, \mathrm{M}$ & 声聞 & $\mathrm{T} 3$ & 0 & 0 & & 天津法 & \\
\hline Am 3 & $75, \mathrm{M}$ & 声䣙 & $\mathrm{T} 1 \mathrm{~b}$ & $\triangle$ & 0 & & 不明 & 白内障，家加占出ない \\
\hline $\operatorname{Am~} 4$ & $73, \mathrm{M}$ & 声門上 & $\mathrm{T} 1 \mathrm{~b}$ & $\triangle$ & 0 & 自然閉銷 & 電気人工啒頭 & 胃癌で罥全摘 \\
\hline Am 5 & $56, \mathrm{M}$ & 声門上 & Tib & $x$ & 0 & 感染・填死 & 人口唉頭 & \\
\hline Am 6 & $56, \mathrm{M}$ & 声閒上 & T3 & $x$ & 0 & 感染・壊死 & 食道発声，母音のみ & \\
\hline Am 7 & $74, \mathrm{M}$ & 声門 & T3 & $x$ & 0 & 感染・壊死 & 人工喉龭 & 胃潰曒で胃切除 \\
\hline Am $8^{*}$ & $67, \mathrm{M}$ & 声閒上 & T3 & 0 & $x$ & 高度の誤呪奬 & 筆談 & 栯尿病 \\
\hline Am 9 & $60, F$ & 声間上 & $\mathrm{T} 2$ & $\triangle$ & 0 & 自然閉鎖 & 食道発声，单語のみ & \\
\hline$A m 10^{*}$ & $72, \mathrm{M}$ & 声門 & T3 & 0 & $\times$ & 高度の誤㗘 & 筆談 & 糖沓病 \\
\hline $\operatorname{Am} 11$ & $51, \mathrm{M}$ & 声門上 & T3 & $\triangle$ & $x$ & 高度の誤蕜 & 筆談 & 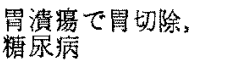 \\
\hline $\operatorname{Am} 12^{*}$ & $74, \mathrm{M}$ & 声閒上 & $\mathrm{T} 2$ & 0 & 0 & & 天津法 & \\
\hline$A m 13$ & $52, \mathrm{M}$ & 声閣 & Tia & 0 & 0 & & 天津法＋食道発声 & \\
\hline Am14 & $59, \mathrm{M}$ & 声門 & $\mathrm{T} 1 \mathrm{~b}$ & $x$ & 0 & 感染・壞死 & 食道発声，音のみ & 精尿病 \\
\hline Am 15* & $48, \mathrm{~F}$ & 乳頭腫 & & 0 & $\triangle$ & & 天津法 & \\
\hline
\end{tabular}

発声: $\bigcirc$ 会話可能, $\triangle$ 発声可能, $\times$ 発声不能.

$*$; 端側吻合

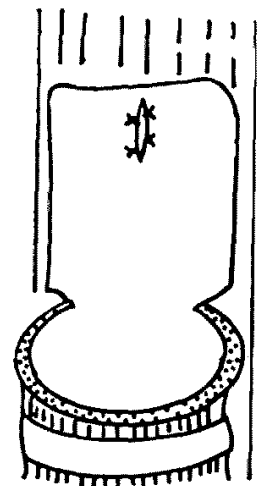

\section{Side-to-side} anastomosis

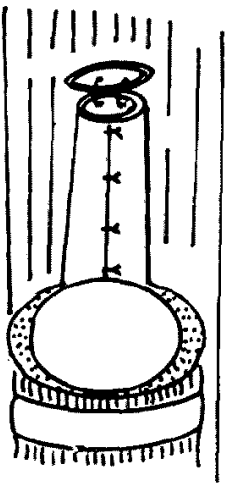

End-to-side anastomosis
図 1 天津法の原法(左) 上变法(右)

6例である．2例（症例 4，9）では会話の絬習が完了し ないろちに，shunt が自然䦕鎖してしまった。また 1 例 （姃例 11）では譟璂が高度なた好沕合部を閉鎖した。残 りの1例（症例 Am 3）は天津法を用いて会話をしょう

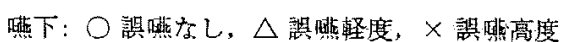

としない75歳の男子で，白内障による視力障害委あり， 家閉じ迅るって社会に出ようとしない人である。

会話ができるようになった6例のうらで，現在も天津 法炕よる発声を続けているの估 4 例（症例 $\mathrm{Am} \mathrm{2,12,}$ 13，15）である. 2例（症例 Am 8，10）では諆䀧が高

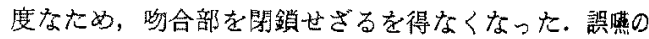
ため shunt を閉した患者（症例 Am 8，10，11）は＂声 は出なくなっても構わないから食事が存分に安心して倉 ベられるようにして欲しい”之強く訴充た。

天津法江よる発声を続けている4例のうちの1例（应 例 Am 15）的諆があり，とく水分をとる時法，吻 合部を指で押皃る必要があるが伆合部の閉鎖を杀望主る ほどではない：また別の1例（症例 Am 13）怯通常の 食道発声も練習し習得した。彼は日常生活で法食道発声 を使用している，話すときに指を使う必要がないからて ある。

発声は可能になったが会話ができるまでにいたらなか った人達の中には，気管孔を押えるのが俑いとか，うま く押えられないと訴える人むいた，天津法炕よる発声は 通常の食道発声よりは容易であるが，会話が可能水なる ためにはゃはり本人の意欲と努力が必要なのである. 
表 3 発声機能検查成續

\begin{tabular}{|c|c|c|c|c|c|c|c|c|c|}
\hline 症例 & $\begin{array}{l}\text { 発声持続時 } \\
\text { 間 (sec) }\end{array}$ & $\begin{array}{c}\begin{array}{c}\text { 平均呼気流率 } \\
\left(\mathrm{cm}^{3} / \mathrm{sec}\right)\end{array} \\
\end{array}$ & $\begin{array}{l}\text { 基本周波 } \\
\text { 数 }(\mathrm{Hz})\end{array}$ & $\begin{array}{l}\text { 声の強さ } \\
\text { (dB, SPI) }\end{array}$ & $\begin{array}{l}\text { 声門下压 } \\
\left(\mathrm{cmH}_{2} \mathrm{O}\right)\end{array}$ & $\begin{array}{c}\text { 声門抵抗 } \\
\left\langle\text { dyn } \cdot \mathrm{sec} / \mathrm{cm}^{5}\right\rangle\end{array}$ & 声門効率 & $\begin{array}{l}\text { 基本周波数 } \\
\text { 域 (半意) }\end{array}$ & $\begin{array}{l}\text { 声の強ざ } \\
\text { 域 (dB) }\end{array}$ \\
\hline Ar 3 & 9.5 & 340 & 120 & 72 & 20 & 58 & $6.0 \times 10^{-6}$ & $20\left(B_{1}-G_{3}\right)$ & $29(62 \sim 91)$ \\
\hline Ar 7 & 33.0 & 60 & 90 & 73 & 90 & 1,466 & $9.5 \times 10^{-6}$ & 測定不能 & $14(74 \sim 60)$ \\
\hline Arlo & 22.0 & 200 & 75 & 75 & 14 & 69 & $2.9 \times 10^{-5}$ & & \\
\hline $\operatorname{Am} 2$ & 14.5 & 120 & 130 & 76 & 57 & 466 & $1.5 \times 10^{-5}$ & & \\
\hline Am:0 & 30.0 & 120 & 100 & 65 & 36 & 294 & $1.9 \times 10^{-6}$ & & \\
\hline$A m: 2$ & 20.5 & 160 & 160 & 64 & 163 & 1,000 & $2.5 \times 10^{-7}$ & $22\left(\mathrm{G}_{1}-\mathrm{F}_{3}\right)$ & $16(60 \sim 76)$ \\
\hline$A m 13$ & 33.2 & 160 & 110 & 62 & 14 & 86 & $1.8 \times 10^{-6}$ & $16\left(G_{1}-B_{2}\right)$ & $18(62 \sim 80)$ \\
\hline Am 15 & 16.7 & 90 & 75 & 68 & 16 & 174 & $1.1 \times 10^{-5}$ & & \\
\hline P 1 & 18.0 & 51 & $50 \sim 80$ & 67 & 24.5 & 470 & $1.0 \times 10^{-5}$ & 測定不能 & $20(62 \sim 82)$ \\
\hline 正常者 & 有 10 以上*1 & $40 \sim 200 * 1$ 男 & $\begin{array}{l}17 \sim 147^{* 2} \\
20 \sim 262\end{array}$ & $\begin{array}{l}\text { 男 } 60 \sim 84^{* 3} \\
\text { 女大 } 60 \sim 80\end{array}$ & $5 \sim 10^{* 1}$ & $20 \sim 100^{* 1}$ & $10^{-6} \sim 10^{-3 * 1}$ & $\begin{array}{l}\text { 男29以上*2 } \\
\text { 女21以上 }\end{array}$ & \\
\hline
\end{tabular}

症例番号は表 1，表 2 番号に一致，Pは Panje 法. 症例 Am15 は女，他はすべて男.

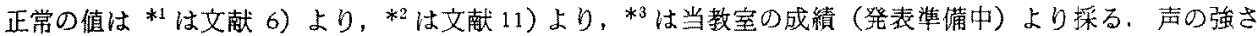
域については適当な参照凟料が見当たらない。

\section{Panje 法}

1例儿本法を使用した，74藏男子て，71嵅の蒔に Arslan-Serafini 法を行い，発声可能になっていたが， 気管孔を拉大したとき吻合部を闒じられてしまった人 （俄1 Ar 11）である.二次的K Panje 法を行い，この 方法によって無殸している。この症例の詳細は别に報告 してある゙

\section{青 発 声 機 能}

Arslan-Serafini 法 3 例, 天津法 5 例, Panje 法 1 例

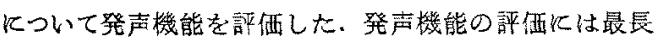

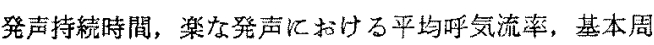
波数，声の強さ，声門下E，声門抵抗，声門效率（激密 には声門と声道を合わせた系の效率）省測定した。また 一部の症例では声の基本周波数域と強さ域をす測定し た、测定は日本音声言語医学会が定めたガイドライン にもとついて行った。

最長発声持緢時間, 平均呼気流率, 基本周波数, 声の 強さの湘定には発声機能検查装置（永島医科機械制製 $\left.\mathrm{PS}_{\mathrm{S}} 77\right)^{12)}$ を用い，声門下压の測定にはU字管を用いた。 声門抵抗は，平均呼気流率と声門下压より算出し，声門 効率は，平均呼気流率，声門下王，声の強さより算出し た.
䒾 3 亿成績を示す．正常者における值は，発严持續時 間，平均呼気流率，声門下王，声門抵抗，声門效率化関 しては文献 6 より，基本周波数と周波数域については沢 島 ${ }^{11)}$ より採た。，声の強さに関しては当教室て Ps-77 を用いて溳定した正常男女各30名の成績より採った。

以下検查項目每注説明する。

\section{1. 最長発声持続時間}

正常者では10秒以上とされている，Arslan-Sarafini 法に9.5秒の例 (Ar 3) がある外は，全例正常筑囲内に ある.3つの手術法の閒に顕著な差は認められない。

2. 平均呼気流率

正常者で $40 \sim 200 \mathrm{~cm}^{3} / \mathrm{sec}$ とされている. ArslanSerafini 法飞 $340 \mathrm{~cm}^{3} / \mathrm{sec}$ の例（At 3) 加ある外林, 全 例正常範囲内纪ある。

\section{3. 声の基本周波数}

沢島 ${ }^{11)}$ の話声位の範囲は，正常な男では117〜147 Hz, 女では $220 \sim 262 \mathrm{~Hz}$ である。 6例 (症例 Ar 7，10，Am $10 １ 3 ， 15 ，$ P 1) 飞扣いて基本周波数は正常者上り低

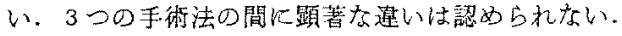

4. 声の強さ

Ps-77 色用いて測定した楽な発声に数ける声の强さの 正常籍囲は，男では60〜84dB，女では60～80dBである. 全例儿沶いて測定值は正常籍国にあり，3つの手術法の 


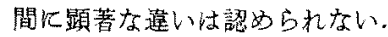

5. 声閒下忹

楽な発声中の声門下环は正常者では 5〜 $10 \mathrm{~cm} / \mathrm{H}_{2} \mathrm{O}$ と されている、いずれの手術法に扎いても，全例声門下压 は大きい，また声門下圧には個人差が大きい，手術法に よる違いは㑇められない。

6. 声閒抵抗

楽な声中の声門抵抗は $20 \sim 100$ dyne $\cdot \mathrm{sec} / \mathrm{cm}^{5}$ とさ れている. Arslan-Serafini 法の2 例 (Ar 3，10）と天津 法の1例 (Am 13) 以外では声門抵抗が大きい，また声 閏抵抗《は個人差が大きい，手術法による顕著な違いは 認为られない。

7. 声門效率

楽な発声炕ける声門の效率は正常者では $10^{-6} \sim 10^{-3}$ のオーダーとされている．天津法の1例（Am 12）て效 率吕悪いが，Zの他の例ではすべて正常筑囲にある.3 つの手街法の間に顕著な違いは認められない。

8. 声の基本周波数域（声域）

䫀定できた 3 例では，全例基本周波数域は低く，关た 周波数域は正常に比して低い方へずれている。

9. 声の强さ域

基本上すべき正常值が見当たらないが，我々の経験て は，25dB 以下の列は稀である，強さ域を測定した 5 例 中4例で $20 \mathrm{~dB}$ 以下であり，狭いと考光られる。

1. 手術法について

\section{IV 総括 と考案}

Arslan-Serafini 法では 11例中 Z例で，嚾下時の下気 道保護上発声の2つの機能について手術は成功した。し かしこの手術法は喉頭蓋を保存てきる例にしか適応がな

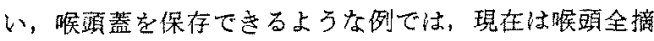
はほとんどの場合必要ない，つまり喉頭を保存する治瘵 法で根治できる、したがって Arslan-Serafini 法は，曼 早搭てられる心きち法である。

天津法では15例中 7 例で，與下時の下気道保護と発声 の2つの機能について手術がーたんは战功した，この他 に3例では発声機能は獾得できたが，下気道保蓝機能の

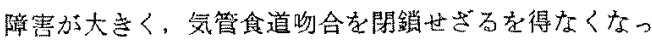
た，我々の施設は医育機関であるので，いらいろのレ心 ルの人が手術を行う，成功率を低いのはこのためであっ て，天津法そのものに久陥があるのではない，本法の㓣 始者天津の成績はもっとよい”。

Panje 法は 1 洌だけの経験であるが，手術は簡学であ
る.手衔に関しては，一定のレベルの人なら，つまり喉 頭全摘がでさる人であれは，誰でも成功する手街法と考 える. 問題恬 voice button が健康保除の適応をうけて

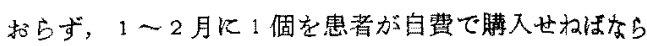
ないことである. Singer-Blom 法 ${ }^{133}$ あ類仪の方法であ るが、同し問題を有する。

2. 発声機能について

発声機能については，3つの方法の間に㩆著な逴いは ない。つ方り成功例の発声機能はどの方法によっても大 差はない，正常者化比へると声の基本周波数が低く，声 閒报抗が大きく，大きい声閒下仕を要する，また声の周

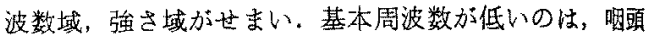

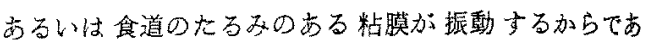
ॐ.

声門提抗が大きく声門下压が大きいとは，発声によ り大きな努力を要することを意味する。つ娄り声带を用 いて挠声するほどには楽でないのである。ささらに指で気 管孔をふさがなけれげならないことは，正常者との大き な違いである。

3. 啹頭全摘後の発声機能はどのようにするのがよいか 天津法は喉頭全摘と同時に行う手術法であるのでこ れが成功すると通常の食道発狮を習得する機会学うこ とになる：士例食道発声も習得した例があったが，これ は例外である、興味あるのは，この例柱食道発声の方妾 常用していることである。つまり食道発声が上手であれ ば，指を用いて話さなりればならない天津法よりも，食 道発声の方が患者に上ってはよいのである。

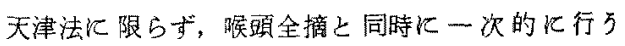
shunt operationはすべて，食道発声㽞得の機会を急者 に与えない，という閶題点をむつ。

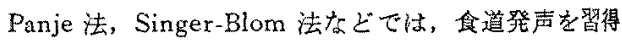
でない人に対して，二次的に手術を行う，し加も手郝

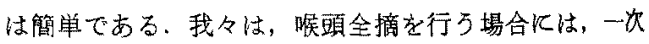
的には shunt operationを行わずに，まず食道発声の 訓練をさせ，食道発声を習得できない人に二次的に Panje 法あるいは Singer-Blom 法を行うのがよいのて はないかと考蛙ている。

な敊前述の上万に㬴頭全摘後の発声は，いずれの方法

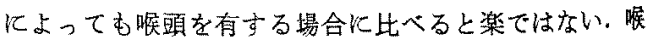
頭全摘は安易に行うべき手街ではない，㩔頭る保存して 治療する方策がどうしてもない場合との夕行うよう，最 大の努力を払わなければならない。この問題については 稿を改めて述へる。 


\section{参苔 文 献}

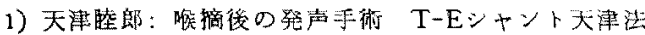
日気食会報 33：123-127，1982。

2）天津睦郎 松居敏夫牧孝金川清人：喉摘後の 音声獲得手術 - One stage て行５新しい術式にっ いて一日耳繁 80: 779-785，1977.

3) Arslan $M$ and Serafini I: Restoration of laryngeal function after total laryngectomy. Report on the first 25 cases. Laryngoscope 82: $1349-$ 1360, 1972.

4）戗井良三: 喉顽形成，第12回口本気管食道稆学会総 会シンポジゥム別册，1960.

5) Bless DM: Personal Communication, 1981

6) Hirano M: Clinical examination of voice. SpringerVerlag, Wien, 1981.

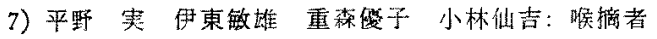

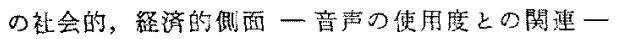
耳参躁床 71: 1287-1295, 1978。

8) 平野 実大久保羊 梁田茂二朗 平出芳生 Diane Bless: Panje $の$ voice button $の$ 使用経䁰 耳窟 28:739-742, 1982 .

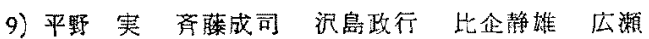

繁: 発声機能惨查施行上，ガイドラインについて

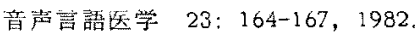

10) Panje WR: Prosthetic vocal rehabilitation following laryngectomy. The voice button Ann Otol Rhinol laryngol 96: 116-120, 1981.

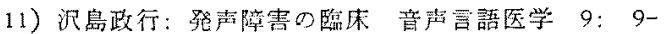
$14,1968$.

12）沢島政行 青木萃夫：発声時の呼気流率，声の高さ 和よび強さの同時部测装圈医器学 52：342-345, 1982.

13) Singer MI and Blom ED: Tracheoesophageal puncture: A surgical prosthetic method for post laryngectomy speech restoration. 3rd International Symposium on Plastic and Reconstructive Surgery of the Head and Neck, 1971.

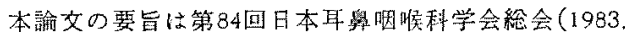
5. 19-21，大阪）に执いて請演した。

(原稿受付 炤和 59，2，13日）

別刷請求先 $\overline{7} 830$ 久留米市旭町 67

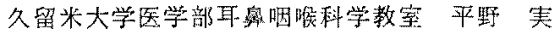

